\title{
POLITYZACJA/MITOLOGIZACJA HISTORII, CZYLI W CZYM NEURONAUKA (1 METODOLOGIA) MOŻE POMÓC BADACZOWI HISTORII NAJNOWSZEJ?
}

\section{ABSTRACT}

\section{THE POLITICIZATION/MYTHOLOGIZATION OF HISTORY OR HOW MIGHT NEUROSCIENCE} (AND METHODOLOGY) SUPPORT THE RESEARCHER OF THE CONTEMPORARY HISTORY

The narratives created by historians with respect to events of the past serve not only the cognitive aims, but may also be used in the current discourse of power and as such be referred to as 'historical politics. In such cases the spotlight is no longer on the historical truth, but rather on the ability to legitimize the power exercised by one social group or political party over the rest of the society. The reason why one reaches for historical myth and politicizes historical narrative is that the emotions evoked in the process can access the mind of a common creator of history (homo historicus) much easier compared to historians' refined analysis based on credible sources and proper methodology. From the perspective of historical politics, a historian - being a rational entity aware of its past (homo metahistoricus) - becomes something redundant, an obstacle that has to be silenced, suppressed or removed. All that matters is homo historicus, as it is the ballot in his or hers hand that will eventually determine winners and losers on election day. As is known, history written by the victors differs substantially from the one written by the defeated. Having diagnosed this way the situation relating to every historian aware of social responsibility of the results of historical studies, the author underlines that historical narrative may be applied to building both positive and negative social capital. The myth and politicization of history act toward dividing a community, rather than uniting it. There is no way to create an effectively operating community without referring to past experiences, although when describing those experiences, it is very easy to fall into various traps of historical thinking. For this reason, neuroscience and methodology are of such a great importance to the historian of the $20^{\text {th }}$ Century History.

\section{KEYWORDS:}

\section{homo historicus, homo metahistoricus, politicization of history, neuroscience, methodology, social responsibility social capital, historical thinking}

Materiał tekstowy udostępniony przeze mnie na stronie Polskiego Towarzystwa Historycznego [patrz: http://pth.net.pl/uploads/forum_badaczy_dn/Polityzacja_historii.pdf] jest zapisem referatu wygłoszonego 10 grudnia 2016 roku w Warszawie na Forum Badaczy Dziejów Najnowszych. Stanowi zarazem wersję roboczą obecnego artykułu, który powstał w nawiązaniu do obrad Forum. 
Historia warstwa wydarzeń powleka zmagania sumień.

$W$ warstwie tej drgaja zwycięstwa i upadki.

Historia ich nie pokrywa, lecz uwydatnia.

Karol Wojtyła, Myśląc Ojczyzna

\section{CZTERY ZAŁOŻENIA WSTĘPNE}

\section{ZAŁOŻENIE PIERWSZE}

Debatując o historii najnowszej, chcemy poruszać się w obrębie społecznej praktyki badań historycznych, a nie w ramach społecznej praktyki politycznej. Każda z tych praktyk społecznych ma swoją „gramatykę", swoje reguły gry. Ale podobnie, jak natychmiast wyczuwamy, gdy ktoś mówiąc, lamie reguly gramatyczne języka polskiego, tak środowisko historyczne jest wyczulone na poprawność/ lamanie reguł naukowości i nadużycie argumentów z historii w debacie publicznej. Czuje się upoważnione do tego, by dbać o jakość edukacji historycznej i kultury historycznej społeczeństwa. Bywa, że dany historyk funkcjonuje i wypowiada się w obrębie każdej z tych praktyk (politycznej i naukowej). Ale wtedy nie powinien przenosić swego autorytetu z jednej na drugą (np. wzmacniać siłę oddziaływania wypowiedzi politycznej dopiskiem „profesor historii” czy, odwrotnie, narzucać jako polityk-historyk swej wizji historii środowisku akademickiemu, np. dyskredytować badania nad życiem codziennym w PRL lub nad historią „żołnierzy wyklętych”, bo... źle mu się politycznie kojarzą) '. Dla czystości debaty publicznej powinien explicite zaznaczać, w jakiej roli aktualnie się realizuje. Na Forum - mam nadzieję - chcemy i będziemy się realizować jako praktykujący badacze dziejów najnowszych².

\section{ZAŁOŻENIE DRUGIE}

Respektując założenie pierwsze, jesteśmy świadomi - rzecz jasna - tego, że historiografia jest w dużej części historią polityki (opowieścią o dziejach „walki o władzę"), a każda polityka jest historyczna w tym sensie, że jest „zawieszona” pomiędzy naszą przeszłością a wyzwaniami dnia jutrzejszego. Dodatkowo, narracje historyczne Lecha Wałęsy.

Albo koniunkturalnie zapowiadać likwidację Instytutu Pamięci Narodowej, by zyskać doraźne wsparcie

2 Dopowiem na wszelki wypadek, iż - jako metodolog - w tym sensie uważam się za osobę praktykującą, iż na ukończeniu mam dwutomowe dzieło Metodologia historii najnowszej. Teoria i praktyka, nad którym pracowałem przez ostatnich kilka lat. 
adresowane są w równym stopniu na rynek wewnętrzny ${ }^{3}$, jak na zewnętrzny, gdzie konfrontują się z odmiennymi państwowymi politykami historycznymi. Nie wolno zatem zapominać, iż polska racja stanu ma także wymiar polityki historycznej ${ }^{4}$ i w tym właśnie międzynarodowym sensie szukałbym argumentu na rzecz polityki historycznej 2.0 - nowego otwarcia w stosunku do debat wcześniejszych, tych z lat 2000-20115 ${ }^{5}$, na powyższy temat. Ale nie tym, międzynarodowym wymiarem, będę się dalej poznawczo zajmował.

\section{ZAŁOŻENIE TRZECIE}

Zarówno mitologizacja historii (rozumiana tu jako intencjonalne tworzenie i posługiwanie się mitami historycznymi dla potrzeb socjalizacji danej wspólnoty), jak i polityzacja historii (rozumiana tu jako intencjonalne podporządkowanie narracji historycznej bieżącym racjom politycznym danej wspólnoty ${ }^{6}$, np. partii politycznej) nie są jedynie pozanaukowymi praktykami społecznymi, spotykanymi we wszystkich krajach. Pozwalam sobie zatem postawić tutaj mocniejszą tezę: mitologizacja/polityzacja historii jest warunkiem niezbędnym, acz niewystarczającym, przetrwania każdej wspólnoty (gwarantuje jej „ontologiczne bezpieczeństwo”, w rozumieniu Anthony’ego Giddensa: zachowania tej części jej tożsamości, która oparta jest na wspólnie przeżytej i podzielanej historii) i jej zdolności do wywołania zmiany społecznej, w sensie, jaki temu pojęciu nadaje teoria stawania się społeczeństwa i historii?

W pełni zgadzam się bowiem z wybitnym polskim socjologiem, Piotrem Sztompką, gdy pisze:

(... ) mechanizmu zmian społecznych na wszelkich poziomach, w tym na poziomie makrospołecznym, a nawet historycznym, szukać trzeba w mikroświecie ludzkich działań, podejmowanych z innymi, obok nich, przeciw innym, czyli w domenie międzyludzkich relacji. Bo w sensie ontologicznym jedyną rzeczywistością społeczną jest to, co dzieje się pomiędzy ludźmi. I tu właśnie kryją się podmiotowe siły sprawcze wszelkich zmian w społeczeństwie ${ }^{8}$.

W tym kontekście właśnie George Orwell mówil, że kto kontroluje przeszłość kontroluje przyszłość.

4 Tak uważał np. redaktor Jerzy Giedroyć, zob.: J. Pomorski, Jerzego Giedroycia rozumienie historii [w: ] Jerzego Giedroycia rozrachunki z historia i polityką. Studia i szkice w czterdziestą rocznicę "Zeszytów Historycznych”, red. S. M. Nowinowski, R. Stobiecki, Łódź 2005, s. 7-19.

5 Zob.: P. Machcewicz, Spory o historię 2000-2011, Kraków 2012.

$6 \quad$ Już Józef Szujski pisał przed laty o fatszywej historyi jako mistrzyni fatszywej polityki. Patrz: Z dziejów odrodzenia politycznego Galicyi 1850-1873 przez M. Bobrzyńskiego, W. L. Jaworskiego i J. Milewskiego, Warszawa 1905.

7 Zob.: P. Sztompka, Socjologia zmian spotecznych, Kraków 2005.

8 Tamże, s. 257. 
Można zatem powiedzieć, używając innej aparatury pojęciowej, że obydwie praktyki społeczne, mitologizacji historii i jej polityzacji, efektywnie służą / mogą służyć budowaniu tego, co nazywane jest dziś „kapitałem społecznym”. Chodzi tu o specjalny, niematerialny rodzaj aktywów, jakie dana wspólnota posiada - o więzi i zaufanie, wytworzone w przestrzeni międzyludzkich relacji na bazie wspólnie podzielanych wartości, przekonań i idei. Także tych odnoszących się do emocjonalnie przeżywanej własnej historii, co nas - jako historyków - interesować musi/powinno żywotnie.

Sztompka zauważa przy tym, iż

kapitał społeczny stanowi wielką wartość, gdy jest dyskontowany z umiarem, w sposób wolny od cynicznego manipulowania innymi i ich wykorzystywania dla własnych egoistycznych korzyści, ale także, z drugiej strony, nie można pozwalać na to, aby inni nim manipulowali i wykorzystywali przeciwko nam ${ }^{9}$.

Warto o tym zawsze pamiętać, gdy myśli się o wykorzystaniu emocji, jakie wywołuje historia, zwłaszcza ta najnowsza, konfrontowana dodatkowo z żyjącymi świadkami wydarzeń! Musimy zatem, jako historycy badający konkretne praktyki społeczne mitologizacji i polityzacji historii, wejść na poziom regut sterujących działaniami w obrębie obydwu praktyk, zrekonstruować gramatyki za nimi stojące i - ewentualnie - dokonać ich dekonstrukcji, jeśli uważamy, że służą nie budowaniu kapitału społecznego, lecz praktykom manipulacyjnym. Czyli postępować analogicznie, jak w przypadku, gdy broniąc konsumentów dekonstruujemy reklamy, by pokazać, w jaki sposób chcą one sterować naszym zachowaniem zakupowym. W tym też pomocne okazują się być neuronauka i metodologia.

\section{ZAŁOŻENIE CZWARTE}

Poszukując przed wielu laty odpowiedzi na pytanie, jakiej historiografii Polacy dzisiaj potrzebują $?^{10}$, zwróciłem uwagę na istnienie swego rodzaju sprzężenia zwrotnego pomiędzy historiografią a aktualnym układem stosunków społeczno-politycznych. Istniejący układ tych stosunków, poszukując akceptacji dla siebie w świadomości społecznej, „domaga się” od historiografii swoistej legitymacji historycznej,

9 Tamże, s. 330.

10 J. Pomorski, Jakiej historiografii Polacy dzisiaj potrzebuja??, „Przegląd Humanistyczny” R.90, nr 6, s. 173-190. 
zakorzenienia swych praw dzisiejszych w tradycji narodowej ${ }^{11}$. A ponieważ w ramach społeczeństwa istnieje zawsze jakaś polaryzacja sił społecznych i opcji politycznych, możemy zaobserwować, jak poszczególne grupy społeczne, klasy i partie polityczne „pilotują” swoje wizje przeszłości, określony typ narracji historycznej, starając się, aby upowszechnił się on, zapanował w świadomości społecznej, wypierając z niej wizje pozostałe. Konstatacja ta nie straciła, jak sądzę, na aktualności.

Stosunek do historiografii był i jest tu w gruncie rzeczy instrumentalny. Nie chodzi bynajmniej o adekwatne odtworzenie przez historyków minionej rzeczywistości, ale o to, by konstrukcja przez nich przedstawiona odpowiadała interesom „mecenasa” i miała społeczne „wzięcie”. Nie o tzw. prawdę historyczną tu chodzi, ale o skuteczność, o społeczną efektywność w budowaniu własnej politycznej sieci relacji w przestrzeni międzyludzkiej ${ }^{12}$. Słowo „własnej” ma przy tym fundamentalne znaczenie. Zasadne jest w związku z tym pytanie, czy jest jeszcze zapotrzebowanie na obiektywną, naukową wiedzę historyczną, dostarczaną przez szeroko rozumiane środowisko akademickie? I czemu/komu ona ma służyć13?

Odpowiadając pozytywnie na pytanie pierwsze, upatruję szans historiografii w realizowaniu jej podstawowej funkcji poznawczej, czyli rozpoznawaniu gramatyk sterujących poszczególnymi rodzajami praktyk społecznych w dziejach (w tym praktyki politycznej), oraz w realizowaniu jej funkcji społecznej, czyli zdolności do wypracowania konsensusu w sprawie tego, co nazywam historycznym bezpieczeństwem

11 A oto konkretny przykład takiej postawy: Nakręcony przed kilku laty w Rosji film 28 panfiłowców opowiada o walce, jaka 28 żotnierzy z 316. dywizji piechoty dowodzonej przez gen. Iwana Panfitowa (stąd "panfitowcy”) stoczyto we wsi Dubosiekowo na przedmieściach Moskwy z niemiecką kolumna pancerną. Wedtug oficjalnej mitologii żotnierze zniszczyli 18 czołgów i zabili kilkuset żotnierzy, zanim wszyscy zginęli. Historia ta była szeroko znana w ZSRR - 28 panfitowców zostato nagrodzonych Orderem Bohatera Związu Radzieckiego, a w kilku miastach bytego ZSRR do dziś stoją ich pomniki. Po upadku ZSRR historycy odtajnili jednak dokumenty Armii Radzieckiej, wedlug których historia boju w Dubosiekowie wyglądata inaczej - część żotnierzy przeżyła, dwóch poddato się Niemcom, a straty wroga byty o wiele mniejsze. Gdy powojenny raport dowództwa Armii Radzieckiej na temat bitwy w Dubosiekowie ujrzat światto dzienne w 2015 r., trwały zdjęcia do 28 panfiłowców. Jak pisat wówczas dziennik „Moscow Times”, reżyser Andriej Szalopa protestowat przeciwko publikacji raportu twierdzac, że << próby obalania przyktadów bohaterstwa narodowego powoduja jedynie ostabianie moralnych podstaw narodu $>>$. http://film.onet.pl/wiadomosci/nowa-rosyjska-superprodukcja-o-bohaterach-wojnynieprawdziwych/zkt517 [dostęp: 04-06-2017].

12 Zmiana pozycji prawdy z wartości na pojęcie stanowi dobrą ilustrację procesu opisanego przez J. Kmitę, wedle którego symbolizowanie aksjologiczne poprzedza semantyczne. Wartości (stany rzeczy wskazywane do osiągnięcia), jakimi są prawda i skuteczność technologiczna, przekształcają się w mierzalne jednostki opisowe - stopień poparcia czy oglądalność. To, co było normą, teraz staje się celem działania. Zob.: A. Pałubicka, Gramatyka kultury europejskiej, Bydgoszcz 2013, s.171.

13 Zob.: B. Wildstein: Jestem w kolegium IPN-u. I uważam, że historycy, którzy tam zasiadają są bardzo sensowni, ale co by szkodzito doprosić paru innych? Nic by się nie stato i dobrze by było. Niestety akcja powoduje reakcję $i$ tak to już jest. Będzie o tyle trudno o kompromisy, że walka toczy się o przemodelowanie rzeczywistości i budowę prawdziwej demokracji, Polska nie jest tak podzielona, jak pokazuja to elity, wywiad dla Onet Wiadomości, 12-11-2016, https://www.google.pl/amp/wiadomości.onet.pl/tylko-w-onecie/bronislaw-wildstein-polska-nie-jest-tak-podzielonajako-pokazuja-to-elity-wywiad/5dwhbe.amp [dostęp:10-06-2017]. 
ontologicznym wspólnoty (czytaj tu: Polski) i jej zdolnością do zmiany zastanego porządku, czyli do tworzenia Historii. Realizując obydwie funkcje na odpowiednio wysokim jakościowo poziomie, służy historiografia równocześnie polskim aspiracjom prospektywnym, zapewniając dla ich skutecznej realizacji niezbędny poziom kapitału społecznego, budowany na wspólnych doświadczeniach historycznych (pozytywna odpowiedź na pytanie drugie).

\section{NASZE DEBATY O HISTORII}

Zwróćmy uwagę, że zasadnie możemy pytać zarówno o to, jakiej historii Polacy dzisiaj potrzebują?, jak i o to, jakiej historiografii Polacy dzisiaj potrzebują? Przeanalizujmy najpierw konteksty, jakie wywołuje to pierwsze pytanie, przyglądając się - modelowo - debacie publicznej, jaka miała miejsce ostatnimi laty w tej sprawie.

Z jednej strony w debacie publicznej mieliśmy zwolenników tzw. historii afirmatywnej (czasami zwanej też „historią monumentalną”), poszukujących, w ramach tzw. polityki historycznej, w przeszłości Polski powodów do narodowej dumy, budowania własnej tożsamości na - wyłącznie ( w wersji „twardej”, czarno-białej) lub przede wszystkim (w wersji „miękkiej”, dopuszczającej jeszcze inny rodzaj patriotyzmu poza tym heroicznym) - chwalebnych kartach z naszej historii ojczystej; przede wszystkim na tradycji niepodległościowej, powstańczo-konspiracyjnej (z powstaniem warszawskim i „żołnierzami wyklętymi” na czele), przeciwstawianej tu jednoznacznie „zdradzie narodowej”, w różnych jej historycznych odsłonach. Dobrym przykładem może być tu środowisko skupione wokół krakowskich „Arcanów”, zarzucające swego czasu IPN pasywność w obronie polskiej historycznej racji stanu. I podkreślające znaczenie ciągłości historycznej dla świadomości narodowej. Prof. Andrzej Nowak w rozmowie z roku 2012 z Jarosławem Markiem Rymkiewiczem pyta:

można odnieść wrażenie, że kończy się historia jako świadomość ciągłości przeszłości. W Polsce widać katastrofalny zanik świadomości historycznej, szczególnie wśród młodszego pokolenia. Stwierdzenie rzecznika SLD, że powstanie warszawskie było w 1988 roku, jest typowe dla pokolenia dwudziestolatków i młodszych. Następuje całkowity odwrót od jakiejkolwiek ciągłości - liczy się tylko dzień dzisiejszy. Czy można mieć jakąkolwiek przyszłość, kiedy się nie ma żadnej przeszłości $?^{14}$.

Z drugiej zaś strony mieliśmy tych, którzy tej „wąsko-narodowej”, „czarno-białej historii Polski” przeciwstawiali „Rzeczpospolitą Wielu Narodów”, z całą jej paletą

14 A. Nowak, Intelektualna historia III RP. Rozmowy z lat 1990 - 2012, Warszawa 2013, s. 651. 
kolorów, wzlotów i upadków, tych dawnych i tych w dwudziestym stuleciu, nie bojąc się mówić Polakom także o tym, czego z naszej przeszłości powinniśmy się wstydzić... ${ }^{15}$

Prof. Jadwiga Staniszkis w rozmowie o polityzacji historii II wojny światowej powiada:

Nie można traktować historii jako narzędzia polityki tożsamości uprawianej tak, jak dzisiaj. Polityzacja historii jest dramatyczna. Część mojej rodziny to Litwini. Walczyli z bolszewikami o niepodległość Litwy. Ale to Litwini byli też używani przez Niemców do pacyfikacji Żydów. Rodzina mojego byłego męża - Żydzi - ukrywała się w Puszczy Knyszyńskiej. To Litwini, nie Niemcy, wchodzili do lasu wypatrywać Żydów. Z drugiej strony kuzyn mojego ojca, też Staniszkis, był dowódcą podziemia koło Mariampola. Wysadził się sam, gdy został otoczony prze NKWD, żeby zniszczyć archiwa. Po której stronie on był? Po stronie Litwy. I z tymi, którzy dawali jej większe szanse. Takie skomplikowane losy trzeba umieć przekazaćl6.

Również toczone w przestrzeni publicznej w owych latach spory i dyskusje o sens powstania warszawskiego, o „żołnierzy wyklętych”, o Jedwabne, o kolejne polskie „miesiące”, o transformację roku 1989, o „III” „IV” RP, żeby wymienić tylko te najważniejsze, dawały asumpt do polaryzacji stanowisk w kwestii tego, co powinno wejść do kanonu polskiej pamięci narodowej.

\section{O DWÓCH POSTAWACH WOBEC RZECZYWISTOŚCI HISTORY[ZNE]}

Historyczność człowieka wyraża się we wtaściwej mu zdolności obiektywizacji dziejów - pisał Jan Paweł II w książce Pamięć i tożsamość.

Człowiek nie tylko podlega nurtowi wydarzeń, nie tylko w określony sposób działa i postępuje jako jednostka i jako należący do grupy, ale ma zdolność do refleksji nad własną historią i obiektywizacji, opisywania jej powiązanych biegów zdarzeń. Taką samą zdolność posiadają poszczególne ludzkie rodziny, jak też ludzkie społeczeństwa, a w szczególności narody ${ }^{17}$.

Bardzo ważne jest to odróżnianie przez polskiego papieża dwóch postaw wobec rzeczywistości: (1) sprawcy historii i (2) reflektującego nad własną historią. Postawa

15 Przywołuję te terminy opisowo, a nie wartościująco, dodam dla porządku, bowiem dobrze pamiętam ostrzeżenie Ajdukiewicza, że wybór języka jest zarazem wyborem ontologii, określonej wizji świata i człowieka, za jaką się opowiadamy.

16 Jadwiga Staniszkis w rozmowie z Michałem Gostkiewiczem, wywiad z września 2016 r. dla magazynu Weekend.Gazeta.pl. http://weekend.gazeta.pl/weekend/1,152121,20591244,taniszkis-ostro-uderza-w-pis-widzeu-nich-wschodnia-mentalnosc.html [dostęp: 04-06-2017].

17 Jan Paweł II, Pamięć i tożsamość, Kraków 2005, s. 78. 
robiącego świat i postawa reflektującego nad światem. Powracając zatem na grunt naszych rozważań, będę dalej posługiwał się pojęciem homo historicus na oznaczenie człowieka jako sprawcy Historii (dziejo-twórcy) oraz pojęciem homo metahistoricus na oznaczenie osoby reflektującej nad historią ${ }^{18}$. To rozróżnienie dwóch postaw: angażującego się bezpośrednio w działanie i obserwatora, podejmującego refleksję nad tym, co robi ten pierwszy, okazuje się być również fundamentem kultury europejskiej, czego dowodzi prof. Anna Pałubicka w Gramatyce kultury europejskiej.

Cechą charakterystyczną kultury europejskiej już od początków czasów nowożytnych, a więc w okresie wczesnego modernizmu, jak starałam się pokazać, jest partycypowanie $\mathrm{w}$ dwóch wyraźnie zarysowanych postawach, które powiązane są z odpowiednim myśleniem i wiedzą. Mamy na myśli postawę człowieka działającego i „robiącego świat” oraz postawę człowieka z dystansu przyglądającego się wszystkiemu co obecne. W postawie zaangażowania jesteśmy spontaniczni, stronniczy, realistyczni i na serio myślimy o świecie. Skoncentrowani jesteśmy na wykorzystywaniu nabytych umiejętności troszcząc się o realizację bliskich nam wartości. Nabywamy poręczności - jak powiedziałby Heidegger - własnej kultury, a więc nabywamy wiedzy o związkach intencjonalnych (o związkach między czynnością a jej sensem). Kiedy zmienimy postawę na kontemplująco-teoretyczną, stajemy się obserwatorami nie uczestnikami wydarzeń. Mamy możliwość oglądu całości, zachowując bezstronność wobec zaangażowanych stron. Możemy zachować dystans względem obserwowanych stanów rzeczy, reflektując nad nimi. ${ }^{19} \mathrm{~W}$ tej postawie dystansu, który przekształca się w nowożytności z kontemplująco-teoretycznego w teoretyczny, wytwarzane są filozoficzne i naukowe, pojęciowe konstrukcje świata. W coraz większym zakresie wspomniane konstruowanie świata, odbywa się w nauce, za pomocą metod naukowych ${ }^{20}$.

Ale czy rzeczywiście mamy szansę na tak pożądaną w nauce bezstronność wobec zaangażowanych stron (na „obiektywizm”)? Zobaczmy, co mówią nam na ten temat współczesna psychologia i neuronauka? Zacznijmy od klasyka psychologii społecznej.

Jonathan Haidt ${ }^{21}$, słynny amerykański badacz postaw moralnych w biznesie i w polityce, dowodzi w swych pracach, że do prawdy prowadzą dwie drogi: droga

18 Homo historicus jako dziejo-twórca to skądinąd tytuł mojej kolejnej książki, nad którą obecnie pracuję.

19 Brytyjski psycholog-ewolucjonista, Robin Dunbar zauważa, że odkrywanie mechanizmów rządzacych rzeczywistościa, czym zajmuje się nauka, jest bardzo interesujące, jednak wcale nie musi zwiększać naszych szans przeżycia. Mało tego, może nawet mieć odwrotny skutek. Z punktu widzenia afrykańskiego Buszmena nie ma sensu wchodzić do jaskini lwa tylko po to, żeby sprawdzić, czy nowo narodzone lwy mają otwarte oczy - zbędna wiedza może kosztować życie. Zob.: Nowa historia ewolucji człowieka, Kraków 2014, s. 205-206.

20 A. Pałubicka, dz. cyt., s. 86-87.

21 Jonathan David Haidt przedstawił wyniki swych badań m.in. w dwóch książkach: The Happiness Hypothesis: Finding Modern Truth in Ancient Wisdom (2006) i The Righteous Mind: Why Good People are Divided by Politics and Religion (2012). 
badacza i droga prawnika. Badacz zbiera dane, szuka w nich powtórzeń, formuluje teorie wyjaśniające poczynione obserwacje, a potem je sprawdza bądź falsyfikuje. Prawnik zaczyna z określonym przekonaniem, określoną tezą, które stara się narzucić innym. Szuka dowodów na ich poparcie, a te, które są mu niewygodne, zwyczajnie pomija. Otóż neuronauka pokazuje, że ludzki umysł został zaprojektowany tak, by pracować w obu tych trybach - być „naukowcem” (mózg świadomy) i być „prawnikiem” (mózg nieświadomy): świadomie szukać obiektywnej prawdy i nieświadomie, z pasją przemawiać za tym, w co chcemy wierzyć. Oba te podejścia spłatają się i przenikają, tworząc nasz światopogląd. Okazuje się jednak, że nie jest to walka równa: badania empiryczne pokazują, że w tej niekończącej się nigdy walce o uzyskanie spójnego i przekonującego obrazu - nas samych i reszty świata (w tym naszej historii) - to pełen zaangażowania „prawnik” zwycięża zazwyczaj „naukowca”.

Psycholodzy nazywają działanie naszego wewnętrznego „prawnika” rozumowaniem umotywowanym. To ten mentalny, włączający się automatycznie, mechanizm naszego umysłu nieświadomego kształtuje sposób, w jaki odbieramy środowisko, w którym żyjemy i pomaga usprawiedliwiać/wytłumaczyć działania, jakie podjęliśmy zgodne z preferowaną subiektywnie ścieżką wyboru. Co nam w tym automatyzmie pomaga? Haidt podpowiada: dwuznaczność. Dwuznaczność, a ściślej mówiąc wieloznaczność tworzy miejsce na lawirowanie w obliczu tego, co w przeciwnym razie byłoby niepodważalną prawdą. Umysł nieświadomy wykorzystuje ten margines bezpieczeństwa, jaki tworzy niejednoznaczność sytuacji społecznych, by tworzyć obrazy nas, innych oraz środowiska, które łączy jedno - wizja najdoskonalszego z dostępnych dla nas losów, która będzie nam dawać sitę $w$ dobrych czasach i oparcie w ztych. Znakomite badania nad tym, w jaki sposób i gdzie ludzie naginają postrzeganie rzeczywistości do swoich pragnień prowadził przez lata zespół neuropsychologów z Cornell University ${ }^{22}$.

Ponieważ rozumowanie umotywowane zachodzi nieświadomie, ludzie naprawdę szczerze stwierdzają, że nie odczuwają uprzedzeń i działają bezinteresownie, nawet jeśli jednocześnie podejmują całkiem wyrachowane decyzje, np. polityczne ${ }^{23}$. To właśnie stronnicze interpretacje dwuznacznych czy - lepiej - niejednoznacznych wydarzeń kryją się za niektórymi z najgorętszych kłótni w sferze publicznej..$^{24}$ Warto w tym

22 Emily Balceris i David Dunning, See What You Want To See: Multinational Influences on Visual Perceptions, „Journal of Personality and Social Psychology" vol. 91, no. 4, 2006, pp. 612-625. Leonard Mlodinow świetnie podsumowuje otrzymane przez nich wyniki: z wielu badań wyptywa ten sam wniosek - tożsamość grupowa jest czynnikiem tak silnym, że będziemy dyskryminować ich na naszą korzyść, nawet jeśli definicja nas i ich sprowadza się do rzutu monetą. Zob.: L. Mlodinow, Nieświadomy mózg. Jak to, co dzieje się za progiem świadomości, wpływa na nasze życie,Warszawa 2016, s.254.

23 Por.: L. Mlodinow, dz. cyt., s. 296-297. W 1998 roku trójka badaczy z University of Washington opublikowała pracę udowadniającą, że uprzedzenia są związane z nieświadomym czy bezwarunkowym stereotypizowaniem. Tamże, s.227.

24 Stronniczość jest immanentną cechą historiografii powiada polski metodolog Wojciech Wrzosek. Zob.: tegoż, O myśleniu historycznym, Poznań 2009. 
kontekście przypomnieć słynne badanie zespołu profesorów psychologii z Princeton i Dartmouth, którzy po upływie roku od wydarzenia postanowili sprawdzić, czy studenci potrafią porozmawiać obiektywnie o ważnym i bardzo głośnym meczu futbolu amerykańskiego, rozegranym przez drużyny akademickie z obydwu uniwersytetów. Oto końcowe zdania $\mathrm{z}$ raportu $\mathrm{z}$ tych badań: te same sygnały sensoryczne zebrane podczas oglądania meczu, przekazane zmysłem wzroku do mózgu wywołały różne reakcje u różnych ludzi. Nie istnieje nic takiego jak istniejący „gdzieś tam” na własnych prawach mecz, który ludzie zaledwie by „oglądali”. Warto to zapamiętać, gdy wrócimy do naszych sporów historycznych i kwestii „obiektywnej” rzeczywistości historycznej: ona jest także ontologicznie i epistemologicznie społecznie kreowana.

\section{CO NEURONAUKA MÓWI NAM O HOMO HISTORICUS?}

Prowadzone od niedawna badania obrazujące pracę mózgu przy pomocy fMRI ( $\mathrm{tj}$. funkcjonalnego obrazowania metodą rezonansu magnetycznego), zaczynają rzucać nowe światło na to, w jaki sposób rodzą się tego typu nieświadome uprzedzenia. Dowodzą one, że gdy próbujemy oceniać dane istotne z emocjonalnego punktu widzenia, nasz mózg automatycznie uwzględnia w ocenie nasze ukryte preferencje, pragnienia i marzenia ${ }^{25}$. Konkretnie chodzi o to, że rozumowanie umotywowane wiąże się z aktywnością tych powiązanych ze sobą rejonów mózgu, które nie mają nic wspólnego z „chłodną” kalkulacją, czyli kory około oczodołowej, przedniego zakrętu kory obręczy - fragmentów układu limbicznego - a także tylnego zakrętu kory obręczy i przedklinka, które uaktywniają się, gdy człowiek wydaje sądy moralnie obciążające. Tak działa neurobiologiczny mechanizm „oszustwa”, którym posługuje się mózg, by wywieść człowieka w pole. A jak działa mechanizm umystowy ${ }^{26}$ ? Do jakich technik nieświadomego rozumowania uciekamy się, żeby utrzymać w mocy obraz świata, który bardziej nam się podoba?

Świadomość nie jest idiota - pisze Leonard Mlodinow.

Gdyby umysł nieświadomy fałszował pogląd na rzeczywistość w nieznany i oczywisty sposób, zauważylibyśmy to i nie zaakceptowalibyśmy podsuwanego obrazu. Rozumowanie umotywowane nie zadziała jeśli będzie żądać zbyt daleko idącej bezkrytyczności. Wtedy samoświadomość będzie wątpić i nici z samooszukiwania się. (...) Aby starannie sfabrykowany obraz samego

25 Zob.: D. Western et al., Neural Bases of Motivated Reasoning: An fMRI Study of Emotional Constraints on Partisan Political Judgment in the 2004 US Presidential Election, "Journal of Cognitive Neuroscience" 18, nr 11, 2006, s. $1947-1958$.

26 Por.: M. Hohol, Wyjaśnić umyst. Struktura teorii neurokognitywnych, Kraków 2013, gdzie można znaleźć bardzo bogatą literaturę przedmiotu. [W marcu 2017 ukazało się wydanie drugie, poprawione]. 
siebie służył ci dobrze, by niósł ze sobą korzyści, niezbędne do przetrwania, musi być wydumany, lecz tylko do pewnego stopnia. Psycholodzy opisują tę równowagę, zaznaczając, że powstałe zaburzenie musi podtrzymywać „iluzję obiektywizmu". W tym wypadku talent, jakim obdarzyła nas natura, objawia się umiejętnością uzasadniania podkolorowanego obrazu samego siebie za pomocą rozsądnie brzmiących argumentów w taki sposób, by uzasadnienie to nie kłóciło się z oczywistymi faktami ${ }^{27}$.

Widać tę iluzję obiektywizmu w polskich sporach wokół polityki historycznej, jakie toczyły się w latach 2000-2011 (by nie odwoływać się tu bezpośrednio do, budzących dodatkowe emocje, przykładów ze społecznej praktyki politycznej w Polsce, z tych i następnych lat) ${ }^{28}$. Może zatem case study z amerykańskiego „podwórka”:

W 2005 roku huragan Katarina zniszczył tereny Luizjany leżące nad zatoką Meksykańską i w delcie Missisipi. Życie straciło ponad tysiąc osób, a setki tysięcy straciły domy. Nowy Orlean został doszczętnie zalany - niektóre obszary miasta znalazły się pięć metrów pod wodą. Reakcja rządu była, mówiąc wprost, ze wszech miar nieudolna. Niemal ze wszech miar. Gdy Michael Brown, dyrektor Federalnej Agencji Zarządzania Kryzysowego został oskarżony o nienależyte wypełnianie obowiązków i brak podejmowania decyzji, a Kongres powołał komisję do sprawdzenia tej sprawy, to czy Brown przyznał się do jakichkolwiek niedociągnięć? Nie. Oznajmił, że słaba reakcja sił rządowych była „wyraźnie zawiniona przez brak koordynacji i planowania ze strony gubernator Luizjany Kathleen Blanco i burmistrza Nowego Orleanu Raya Nagina. W rzeczywistości urzędnik zdawał się postrzegać samego siebie jako swoistego rodzaju postać tragiczną, niemal równą mitologicznej Kasandrze. Powiedział nawet: „Prywatnie od lat przewidywałem, że brak środków i odpowiedniej uwagi doprowadzi nas do tego punktu[kryzysowego $]^{29}$.

Iluzja obiektywizmu zatem to kolejne pojęcie do słownika terminów podstawowych historyka dziejów najnowszych. Następne to pamięć utajona, bowiem dla neuronauki podświadomość to przeszłość zapisana w mózgu ${ }^{30}$.

W 1985 roku Daniel Schacter i Peter Graf dokonali rozróżnienia pomiędzy pamięcią jawną a utajoną, a w 2003 roku dwaj światowej sławy badacze, Brian Kolb i Ian Q. Whishaw, opisali odmienne struktury mózgu odpowiedzialne za jedną i za drugą, dowodząc tym samym rozłączności dwóch systemów pamięci. Pamięć jawna

27 L. Mlodinow, dz. cyt., s. 303-304.

28 Zob.: P. Machcewicz, Spory o historię 2000-2011, Kraków 2012.

29 L. Mlodinow, dz. cyt., s.287. Co ciekawe, ludzie nie cofaja poparcia dla ulubionych polityków, nawet jeśli dobrze udokumentowane i poważne oskarżenia ujrza światło dzienne, a drugiej strony z łatwościa przyjmuja, że zastyszana gdzieś pogłoska o nieprawidtowym skręcie w lewo polityka innej partii jest wystarczajacym powodem, by dożywotnio zakazać mu udziatu $w$ życiu publicznym. Tamże, s.306.

30 Zob. na ten temat: Rafał Ohme, Emo Sapiens. Harmonia emocji i rozumu, Wrocław 2017. Dziękuję Profesorowi za możliwość zapoznania się z tą pracą przed jej formalnym wydaniem. 
wspomaga nas na zawołanie, kiedy tylko chcemy coś sobie przypomnieć lub rozpoznać (zaklasyfikować) jakąś rzecz bądź zjawisko. Pamięć utajona to wiedza, jaką zgromadziliśmy, utrwaliliśmy neurochemicznie w mózgu, ale świadomie... nie pamiętamy. To, że coś pamiętamy, mimo że sądzimy, że nie pamiętamy, jest faktem naukowym. Dzięki neuronauce i metodzie obrazowania wiemy dziś nawet, kiedy i gdzie w mózgu zapisują się ślady pamięciowe. Tak więc podświadomość to obecnie już nie Freud, nie Ego, zmagające się z Id i z libido, ale wiedza, którą zdobywamy przez całe życie i zapisujemy w pamięci. Generalnie sama pamięć, to nic innego jak nasza przeszłość, obecna w mózgu i czekająca jedynie na pobudzenie/przebudzenie. Część wspomnień mamy jakby na wyciągnięcie ręki. To te, które zlokalizowane są w pamięci epizodycznej, czyli takiej, która dotyczy wydarzeń z naszego życia codziennego. Jeśli chcemy, możemy je przywołać. Gasną, jeśli do nich nie wracamy, choć wiele z nich pozostaje $\mathrm{z}$ nami $\mathrm{w}$ formie utajonej do końca życia. Inne rzeczy pamiętamy, jakbyśmy mieli w głowie „twardy dysk” - stolice krajów Europy, daty z historii Polski, itp. - to pamięć mechaniczna. Mamy jeszcze inne: pamięć ruchowa, do której odwołujemy się np. gdy jedziemy na rowerze lub wiążemy krawat, pamięć smaków czy pamięć stuchowa, a nawet pamięć dotykowa. Wszystkie dostępne dla świadomości informacje to jednak tylko mały ułamek w porównaniu z gigabajtami wiedzy, jaką gromadzi pamięć utajona. Oddajmy zresztą głos Rafałowi Ohme:

Wspomnienie jest zapisanym stanem pobudzenia pewnego układu neuronów w mózgu. O tym, czy coś ma być zapamiętane, decyduje hipokamp - część układu limbicznego. Sprawia on, że dochodzi do zmian w błonach neuronów i stężenia neuroprzekaźników (np. acetylocholiny, adrenaliny i wazopresyny) w niektórych synapsach. Powstaje wtedy engram, czyli jednostka wspomnienia, ślad pamięciowy w postaci materialnej zmiany pozostawione przez określone przeżycie lub bodziec w układzie nerwowym (głównie w ciele prążkowanym, ciele migdałowatym i korze). A zatem pamięć [w świetle neurobiologii - dopisek mój - JP] to materialna konsekwencja aktywności biochemicznej mózgu. (... ) Aktywizując te, a nie inne engramy możesz odtworzyć informację, czyli sięgnąć do pamięci - świadomie lub bezwiednie. Żeby to, co przeżywasz zapisało się w pamięci na stałe, żeby powstał engram, musi dojść do trwalej zmiany w budowie synapsy. Tak się dzieje, gdy operujesz jakąś informacją przez mniej więcej 12 minut. Dochodzi wtedy do konsolidacji śladu pamięciowego. Taka zmiana zostanie z tobą do końca życia, tyle, ze nie zawsze będziesz mieć do niej dostęp . Posługując się metaforą komputerową, możesz stracić „ścieżkę dostępu”, ale sam „plik” będziesz mieć zapisany ${ }^{31}$.

31 Tamże, s. 259-262. 
Do większości śladów pamięciowych (pamięci utajonej) nie mamy, jako homo sapiens, świadomego wglądu, a mimo to właśnie one modyfikują sposób, w jaki widzimy otaczający nas świat. Wpływają na to, co robimy i jakie decyzje podejmujemy. Przebadał to i znakomicie opisał laureat Nagrody Nobla z ekonomii Daniel Kahneman, dowodząc w Pułapkach myślenia ${ }^{32}$, że zakładany dotąd model racjonalności ludzkich osądów, decyzji i wyborów nie da się dłużej utrzymać, w świetle tego, co już wiemy dzięki neuronauce o naturze ludzkiego umysłu. W szczególności nie da się obronić koncepcji homo oeconomicus, jako podstawy ludzkich zachowań na rynku gospodarczym. To nie świadomość, ale podświadomość jest odpowiedzialna za większość naszych decyzji, w tym zakupowych, które następnie post factum próbujemy jakoś racjonalizować, usprawiedliwiać przed samym sobą, rodziną czy znajomymi, wpadając przy tym w rozmaite „pułapki myślenia”. Dzięki neuronauce wiemy też, że nasza pamięć nie działa jak kamera, która wiernie zapisuje scena po scenie całe życie na płycie DVD (marzenie wielu historyków wizualnych). W ludzkiej głowie siedzi raczej „filmowy montażysta”, który nie dość że wybiera tylko pasujące mu do subiektywnego światooglądu „ujęcia” (kadry), to jeszcze potrafi opatrzyć je tendencyjnym komentarzem, uwypuklającym własne racje, a umniejszający znaczenie tego, co twierdzi druga strona... Pamięć utajona dopuszcza się zniekształceń w procesach zapisywania, przetwarzania, a ostatecznie także w czasie wydobywania informacji - oto, poparte licznymi badaniami, jedno z podstawowych twierdzeń neuronauki i kolejna lekcja do odrobienia dla badaczy pracujących ze „źródłami osobowymi”.

A przy tym, nasz nieświadomy mózg ma nie tylko gatunkową (biologiczną/ zwierzęcą) naturę, ale jest on współtworzony przez relacje społeczne, jakie w toku swego życia człowiek nawiązuje ${ }^{33}$. (Notabene, metodologia i filozofia nauki potwierdzają to również, jeśli chodzi o część świadomą mózgu). To właśnie one - sieci relacji społecznych w przestrzeni międzyludzkiej - kształtują nasze człowieczeństwo, jako istot społecznych ${ }^{34}$. Homo historicus to nie homo sapiens, ale Emo sapiens, by użyć terminu prof. R. Ohme: człowiek, którego wyborami sterują emocje a nie racjonalne argumenty. To nieświadoma składowa mózgu homo historicus, jego pamięć utajona, podpowiada mu rodzaje zachowań, gdy zostanie postawiony przez Historię w sytuacji decyzyjnej. Musiało to mieć miejsce także w przypadku tych najważniejszych w naszej historii najnowszej wydarzeń. Ich sprawcy działali racjonalnie, a badacz dziejów najnowszych musi brać już ten wymiar rerum gestarum na wokandę swojego warsztatu.

32 D. Kahneman, Pułapki myślenia. O myśleniu szybkim i wolnym, Poznań 2012.

33 Świetnie to pokazuje R. Dunbar, dz. cyt. Zob. też część II cytowanej książki Mlodinowa, a także J.-C. Kaufmanna, Ego. Socjologia jednostki. Inna wizja człowieka i konstrukcji podmiotu, Warszawa 2004, zwłaszcza część I.

34 Każdy człowiek ma unikalną historię relacji, rzecz jasna, i im bardziej są one sieciowo rozbudowane, tym są cenniejsze. 


\section{O POTRZEBIE UPODMIOTOWIENIA HOMO HISTORICUS}

A jeżeli zależy nam na podmiotowości społeczeństwa, na świadomym stawaniu się/ wytwarzaniu historii (nie - historiografii, ale Historii)? Przypomnijmy najpierw, co mówi o tym procesie teoria stawania się dziejów. Sztompka pisze, iż jest to ustawiczny proces reprodukowania, samoprzekształcania i samotworzenia się społeczeństwa, realizujący się w ciągłej, obustronnej interakcji między tym, co potencjalnie możliwe (osiągniętym stopniem podmiotowości), a tym, co aktualnie zrealizowane (rzeczywistą praktyką), w ciągłym współkształtowaniu jednego przez drugie. Tak więc społeczeństwo nigdy w jakiejś ostatecznej postaci nie istnieje, lecz zawsze się staje. Nigdy nie jest, lecz zawsze się tworzy. Nie stanowi obiektu, stanu, lecz proces. Nie jest czymś danym, lecz każdorazowym własnym osiągnięciem członków społeczeństwa, „przedsięwzięciem w budowie", przy tym w budowie nigdy ostatecznie niezakończonej ${ }^{35}$.

Jeśli zgodzimy się, że w sensie ontologicznym jedyną rzeczywistością społeczną jest to, co dzieje się pomiędzy ludźmi, to właśnie dzieje tego „dziania się pomiędzy ludźmi” stanowią przedmiot naszego poznania, jako historyków.

Oba czynniki składające się na praktyki zmieniające społeczeństwo, czyli właściwości samych jednostek i cechy struktur, w obrębie których działają, dadzą się wywieść z charakteru ich prywatnych sieci relacji oraz zbiorowych sieci relacji w grupach, do których należą, czyli z kształtu indywidualnych i zbiorowych przestrzeni międzyludzkich ${ }^{36}$.

Jako jeden pierwszych zwrócił na to uwagę Randall Collins. Według niego, interakcja twarzą-w-twarz, o małej skali, zachodząca tu i teraz, jest podstawowym ogniwem, podstawową sceną procesu generowania (czyli tworzenia) Historii oraz najważniejszym terenem działania aktora społecznego - sprawcy historii (homo historicus). Jeżeli chcemy odnaleźć sprawcza podmiotowość (agency) życia społecznego, to znajduje się ona właśnie tutaj. W niej tkwi energia ruchu i zmiany, spoiwo solidarności oraz konserwatyzm zastoju. To tu lokuja się intencjonalność $i$ świadomość, tu także jest miejsce dla istnienia emocjonalnych i nieświadomych aspektów ludzkiej interakcji - powiada Collins ${ }^{37}$.

W podobnym duchu wypowiada się też Anna Pałubicka:

35 P. Sztompka, Kapitat społeczny. Teoria przestrzeni międzyludzkiej, Kraków 2016, s. 256.

36 Tamże, s. 257.

37 R. Collins, Łańcuchy rytuatów interakcyjnych, Kraków 2011, s. 17. 
Przemiana, o której mowa, tradycyjnego odbiorcy w uczestnika, współtwórcę wydarzenia dokonuje się poprzez jego zaangażowanie w działania. Porusza się wówczas sferę doznań podmiotu, a więc jego pragnienia, wyobrażenia i wrażliwość. Są to najbardziej na serio brane elementy osobowości człowieka, dla niego rzeczywiste i autentyczne. W happeningach, w sztuce typu performance dochodzić może do rozszerzania się sfery przeżyć podmiotu poprzez wywołanie nowych, zaskakujących emocji ${ }^{38}$.

Zjawisko to spotykamy także w ruchach rekonstrukcyjnych, które ujawniają bardzo często zaskakujące dla samych uczestników pokłady emocji związanych z przeżywaniem historii.

O wiele większe znaczenie dla przemian historycznych ma jednak uświadomienie sobie przez homo historicus, że może on nie tylko nieświadomie, ale także podmiotowo, w pełni świadomie mieć wpływ na zmianę społeczną, na bieg Historii. Wielu badaczy np. uważa, że pozostając na poziomie homo sapiens, racjonalnym, nie da się wyjaśnić, jak mogło dojść do pokojowego obalenia komunizmu? Prowadząc refleksje nad Czasem Przełomu, czyli okresem pierwszej „Solidarności” i transformacją ustrojową, zapoczątkowaną wyborami 4 czerwca 1989 roku, próbując poznawczo zrozumieć, co było możliwe w tamtym czasie i dlaczego możliwość stała się historyczną koniecznościa, rozpoznaję tę zmianę jako zmianę społecznych systemów wartości i rozumienia własnej podmiotowości. To, co jest istotą solidarnego społeczeństwa obywatelskiego, to zasada podmiotowości i samorządności wcielona w praktykę.

Zauważmy, że już samo postawienie problemu w ten sposób, zasygnalizowana opozycja postaw społecznych: człowiek solidarności versus homo sovieticus - tak znakomicie zarysowana w Etyce Solidarności przez ks. prof. Józefa Tischnera - ma kapitalne znaczenie, bowiem po to chcemy - jako reprezentanci różnych nauk społecznych - wspólnie prowadzić namysł nad tą Wielką Zmianą, by koncepcyjnie odnaleźć źródła ówczesnych naszych sukcesów. Transformacja jest faktem dokonanym, niezależnie od tego, jak dziś oceniamy obecny stan spraw polskich. I nie był to - jak sugerowali Jadwiga Staniszkis i Andrzej Zybertowicz - żaden spisek tajnych służb (w sensie warunku wystarczającego lub warunku niezbędnego, jaki może wystąpić w związkach przyczynowych pomiędzy A i B). Gdzie więc poszukiwać warunków niezbędnych, wystarczających i sprzyjających tamtym wydarzeniom? Osobiście „klucza” do zrozumienia historii polskiej transformacji poszukiwałbym w tym, co było podstawą całego ruchu społecznego „Solidarności” a co można by nazwać solidarnością obywatelską, szczególnym rodzajem kapitału społecznego, jaki udało się nam wówczas wytworzyć. Ma rację wybitny polski socjolog, gdy pisze: Dysonans między wielką szansą wolności,

38 A. Pałubicka, dz. cyt. s. 189. 
jaka przyniósł nam rok 1989, a jej dzisiejszym wykorzystaniem to nasza ogólnonarodowa trauma transformacji ${ }^{39}$ i dobrze byłoby wreszcie to zmienić, odnajdując klucz do zrozumienia, na jakim kapitale społecznym wówczas bazowaliśmy, sami o tym nie wiedząc czy nie mając pełnej tego świadomości.

Problem „Solidarności” polega na tym, iż z gruntu nietrafnie rozpoznawano jej istotę: albo patrzono na nią jako na quasi-partię polityczną, albo widziano w niej związek zawodowy. Przypomnijmy sobie do czego to prowadziło: gdy stawała się quasi-partią - ponosiła klęskę za klęską, gdy wmawiano jej, iż powinna być tylko związkiem, marginalizowała się, tracąc swoją siłę sprawczą do wielkiej zmiany. Na początku lat osiemdziesiątych „Solidarność” była czymś innym; posiadała idiom, który nadal nie jest adekwatnie objaśniony, a dzisiaj czeka na nowe odczytanie w kontekście obecnych wielkich pytań (np. kwestii globalnych nierówności). Niestety, również jako środowisko naukowe nie potrafiliśmy i nie potrafimy nadal, jak sądzę, do końca rozpoznać swoistości tego fenomenu. To wyjście ze sfery prywatności, przekraczanie własnych egoizmów było widoczne jeszcze na przełomie 1989 i 1990 roku, gdy ludzie z masowo wtedy zakładanych komitetów obywatelskich spotykali się, by wspólnie naprawiać dom, któremu na imię Polska (dla tych, którzy lubią narodowy patos) lub (dla tych, którzy preferują np. historię codzienności), by zwyczajnie zbudować osiedlową drogę, sklep czy szkołę. Ale bardzo szybko świadomość tego, co nas połączyło w roku 1980 i co dawało nam siłę sprawczą - zagubiliśmy ${ }^{40}$. Była „wojna na górze”, kazano nam się politycznie podzielić, organizować w partie, pękła solidarność między ludźmi, przestaliśmy być kreatorami własnej lokalnej rzeczywistości. A potem ogłaszano kolejne „wojny polsko-polskie”; musisz się zdeklarować, opowiedzieć za kim jesteś $^{41}$. Ten podział - polityczny w istocie - miał się stać ważniejszy niż to, co było istotą pierwszej „Solidarności” i co mogło być naszym, Polaków, największym atutem w XXI stuleciu, kapitałem społecznym, umożliwiającym modernizację wszystkich obszarów funkcjonowania państwa i wykorzystanie szans rozwojowych, jakie przed Polską powstały.

39 P. Sztompka, Trauma wielkiej zmiany, Warszawa 2000.

40 Zgadzam się z Anną Pałubicką, gdy pisze: Społeczeństwo uwierzyło, że jest zbiorem tylko jednostek, każda jednostka zainteresowana jest tylko tym, co przeżywa. Odrzuca trzecioosobowy dystans wobec świata niezbędny w uczestniczeniu $w$ sferze publicznej i obowiązujący w niej sposób myślenia oparty na racjonalnej argumentacji, oddając się sferze wtasnych przeżyć. Taż, dz. cyt., s.58.

41 Podzielam porażającą konstatację Grzegorza Sroczyńskiego, wypowiedzianą w kontekście jubileuszu 40-lecia KOR: Chyba nie można myśleć o kimś gorzej niż dawni przyjaciele z KOR o sobie nawzajem. (...) Nie rozumiem tego. Po prostu nie rozumiem, co się stało z waszym pokoleniem [Do mistrzów z KOR, felieton „Dużego formatu” 22-092016]. Zamieszczone w „Dużym formacie” rozmowy z Zofią Romaszewską oraz z Ludmiłą i Henrykiem Wujcami, tylko ten ból potęgują. 


\section{POLSKI HOMO METAHISTORICUS I WYZWANIA PRZED NIM STOJĄCE}

Prawdziwym wyzwaniem, przed jakim staje dziś polski historyk jest, jak nauczyć rodaków rozumienia drogi, jaką wspólnie przebyliśmy, by znaleźć się tu, gdzie dziś jesteśmy i wobec wyzwań, które współczesny świat stawia przed nami. I jak uczyć Polaków tego, co metodolodzy historii nazywają myśleniem/działaniem dziejotwórczym: aktywnej postawy wobec rzeczywistości, wynikającej z popartego wiedzą historyczną przekonania, że zmiany są w ogóle możliwe (czego nie raz w naszych dziejach dowiedliśmy w praktyce, z obaleniem komunizmu bez przemocy włącznie, dokonując pokojowej rewolucji, która bezpowrotnie zmieniła historię XX stulecia), że to my naszymi codziennymi działaniami tworzymy historię, a skuteczność w realizacji projektów, tak jednostkowych, jak i społecznych, zależy od tego, jaki kapitał społeczny w lokalnej czy - powiedzmy - narodowej przestrzeni międzyludzkiej uda nam się wytworzyć/zbudować i zaangażować w dane przedsięwzięcie. Pokazanie tego, że za każdym projektem, za każdym wielkim wydarzeniem w naszej historii, stał niezbędny poziom kapitału społecznego, jaki musiał połączyć Polaków, aby dane wydarzenie w ogóle mogło zaistnieć, stać się faktem dokonanym, a w swym „życiu po życiu” (bo każde wydarzenie skoro już zaszło, zyskuje swoje „drugie życie”, w pamięci społecznej i w historiografii) być przedmiotem dumy a czasem wstydu - to największe wyzwanie intelektualne dla historyka i największa frajda, jeśli uda mu się tego w książce, na wykładzie czy na lekcji historii - dokonać.

Homo metahistoricus, czyli człowiek zdolny do reflektowania nad własną historią i opowiadania innym o tym doświadczeniu to, rzecz jasna, nie tylko zawodowy historyk, ale tu chciałbym się skupić wyłącznie na społecznej praktyce badań historycznych, operując modelowym przykładem badacza dziejów najnowszych. Przed jakimi pułapkami intelektualnymi (pułapkami myślenia historycznego) staje badacz dziejów najnowszych, gdy chce opowiedzieć swym Rodakom, co się nam wspólnie przydarzyło w XX stuleciu?

\section{PU ŁAPKA PIERWSZA: OPEROWANIE WY $Ł A ̨ C Z N I E$ CZASEM PRZESZŁUM DOKONANYM}

Historyk zwyczajowo operuje czasem przeszłym dokonanym: wie, co faktycznie stało się post factum, a czego nie mogli wiedzieć/przewidzieć bohaterowie opisywanych przez niego zdarzeń. I właśnie ta wiedza jest pierwszą z pułapek intelektualnych, na 
którą warto zwrócić uwagę. Może narzucać określoną perspektywę narracji historycznej. Skoro wiem, jak to się wszystko skończyło, to ta wiedza finalna „podpowiada” mi perspektywę, z jakiej będę się przyglądał wydarzeniom historycznym in statu nascendi. To tak, jakby zacząć czytać kryminał od zakończenia, w którym narrator wyjaśnia, kto i dlaczego zabil. A przecież nie da się zrozumieć historii, jeśli nie potrafimy, jako narratorzy opowieści historycznej, pokazać konkretnych ludzi w ich rzeczywistych sytuacjach decyzyjnych, w jakim przyszło im działać. Oni nie dysponowali wiedzą, co zdarzyło się potem, a przecież musieli dokonywać wyboru, musieli działać, często przy szczątkowej wiedzy o okolicznościach (kontekstach), które takiemu działaniu towarzyszyły. Prof. Jadwiga Staniszkis:

Polska jest krajem, gdzie podejmowano miliony indywidualnych decyzji, czy być bohaterem, czy zdrajcą. Kryła się za tym jakaś kalkulacja. Ocena ryzyka. Kosztów. ( ... ) To, co w historii powinniśmy teraz pokazywać, to całą złożoność peryferii Wschodu i Zachodu, na których znajduje się Polska. Złożoność sytuacji. Historii nie można przedstawiać jako jednoznacznego podziału racji. [podkreślenie moje - JP] Jeżeli ta wiedza, którą mamy, nie przetrwa, to będziemy mniej wiedzieli o sobie ${ }^{42}$.

\section{PUŁAPKA DRUGA: POPRAWNOŚĆ HISTORYCZNA}

Pułapką drugą, przed jaką staje homo metahistoricus jest ucieczka w poprawność polityczną. Przejdźmy zatem do namysłu nad polityczną poprawnością i jej składową - poprawnością historyczną. Polityczna poprawność nie musi być skodyfikowanym ani spójnym zbiorem zasad (choć w tej właśnie postaci także występuje, zwłaszcza w USA i w Europie), lecz zjawiskiem społecznym, polegającym - w skrócie - na zwalczaniu w dyskursie publicznym (głównie w mediach oraz poprzez tzw. hejt lub/i ostracyzm towarzyski) osób/wypowiedzi, które naruszą (niepisane lub spisane) zasady politycznej poprawności. Zasady te, historycznie zmienne rzecz jasna, wyznaczają granice zachowań werbalnych i pozawerbalnych, które są dopuszczalne i których przekroczenie oznacza złamanie współczesnego społecznego tabu i w konsekwencji jakiś rodzaj wykluczenia ze wspólnoty. A jak to wygląda w przypadku poprawności historycznej? Jak zmienia się jej main stream i kto wyznacza, co jest aktualnym głównym nurtem w jej zakresie? Bo na pewno nie akademickie środowisko historyczne. Czy zatem tzw. opinia publiczna(czytaj: media)? Politycy?

Mamy świadomość tego, że poprawność polityczna jest z reguły wyrazem przemocy intelektualnej, stosowanej wobec uczestników publicznej debaty. Przemoc

42 J. Staniszkis, dz. cyt. 
narzuca światoogląd, inicjuje „consensus pierwotny”, jakby powiedział Andrzej Zybertowicz, narzuca dopuszczalne języki dyskursu (odradza komunikację), socjalizuje wspólnotę kulturową i wyznacza ramy (granice) dopuszczalnych gier kulturowych ${ }^{43}$. W tym sensie kreuje kulturowe środowisko dla wszelkich debat publicznych, w tym debat historycznych. Wieloperspektywiczność zostaje zredukowana do dwóch przeciwstawnych punktów widzenia: zdominowanego i dominującego, kolonizatora i skolonizowanego.

W literaturze przedmiotu zwraca się uwagę na opresyjność, wynikającą z konieczności respektowania normy „poprawności politycznej” w dyskursie publicznym. Występuje ona już na poziomie „przemocy symbolicznej” (Pierre Bourdieu), czyli narzucaniu w procesie edukacji kategorii poznawczych, które sprawiają, że zdominowany nie jest w stanie nazwać swojej podległości i się przeciw niej zbuntować. Historia opowiadana jest z perspektywy zwycięzców, zwyciężeni nie mają prawa głosu, skonstatował swego czasu Walter Benjamin, a Krzysztof Pomian uczynił z tego jedną z ważniejszych kategorii analiz historiograficznych. Warto w tym kontekście przywołać wypowiedź Andrzeja Chwalby, który zauważa, iż

$\mathrm{w}$ poprzednich dekadach działał w Europie zachodniej pewien rodzaj politycznej poprawności, opartej na przeświadczeniu, że zarówno ideologia, jak historia są czynnikiem podziałów i konfliktów. W dobie integracji europejskiej uznano zatem, że należy je eliminować jako szkodliwe (...). Niegdyś historycy byli akuszerami narodów europejskich, oni je tworzyli, nadawali im zakorzenioną w dziejach tożsamość. Zatem, gdy powstać miała w Europie Zachodniej ponadnarodowa wspólnota, należało te różnicujące elementy zarzucić. Uznano więc potrzebę przezwyciężenia historii ${ }^{44}$.

43 Zob.: A. Zybertowicz, Przemoc i poznanie, Toruń 1996, s. 206-207. Chciałbym przy tej okazji powiedzieć polemicznie w stosunku do Profesora Andrzeja Nowaka, że specyfika metodologiczna historiografii IPN jednak istnieje, nie ze względu na środowisko historyków tam pracujących czy ich kompetencje, ale na zasób źródłowy tu archiwizowany - wytwór praktyk przemocy, narzucających określoną optykę, zgodną z „gramatyką” działań służb. Zob. odnośną wypowiedź Andrzeja Nowaka: Nie widzę zatem interesującej poznawczo możliwości wskazania specyfiki „historiografii IPN” na płaszczyźnie metodologicznej. A jednak takie pytanie jest postawione. Muszę zatem wrócić do mojego pytania: zjakiej perspektywy kwestia postaw metodologicznych pracowników IPN jest stawiana? Czy z jakiejś neutralnej, naukowej, wobec której perspektywa IPN bytaby nie do końca <<neutralna >>czy <<naukowa >>? Przypomina mi się tutaj powiedzenie Karla Mannheima: <<Co dla jednego badacza jest nauka, dla drugiego może być ideologią >>. Pozwolę sobie odwrócić tę uwagę w kierunku tych, którzy stawiają pytania wobec Instytutu. Ich pytania moga mieć tak samo charakter ideologiczny, jak prace powstałe w kręgu IPN i, naturalnie, jak moje przemyślenia w tej sprawie, tegoż: Tragedia IPN [w:] Bez taryfy ulgowej. Dorobek naukowy i edukacyjny Instytutu Pamięci Narodowej 2000-2010, Łódź 2012, s. 29.

44 Czy wystarczy prawda historyczna, Andrzej Chwalba w rozmowie z Januszem A. Majcherkiem, „Przegląd Polityczny”, nr 75, 2006. Cyt. za: Nie ufam wtasnej pamięci. O tajemnicach Krakowa, carskiej i sowieckiej Rosji i nie tylko... Rozmowy z Andrzejem Chwalba, Kraków 2008, s. 170-171. 


\section{PUŁAPKA TRZECIA: UCIECZKA OD HISTORII, NA DWA SPOSOBY}

To przezwyciężanie historii przyjęło postać ucieczki od niej. Ucieczki na dwa sposoby. Pierwszy sposób polegał na tym, co celnie opisał Norman Davies, zauważając, iż w ramach nowej politycznej poprawności historycznej
w naszych szkołach wyszło z mody nauczanie tradycyjnej historii, pojętej jako krytyczne badanie przeszłości oraz procesów zmian i konfliktów. W miejsce racjonalnego krytycyzmu nasze dzieci są uczone „empatii”, mają rozbudzać w sobie gorące emocje w stosunku do „ciemiężonych” - grup społecznych wybranych i zdefiniowanych przez nauczycieli. Napisz wypracowanie na dwieście słów na temat uczuć dziecka/kobiety/homoseksualisty pobitych przez policję w Nikaragui/ Afryce Południowej/Kalifornii ${ }^{45}$.

Zauważmy, że nauczanie historii jest tu sprowadzone do nauki poprawności historycznej, rozumianej zgodnie $\mathrm{z}$ aktualną wykładnią tego pojęcia, a nie np. do nauki krytycznego myślenia historycznego, zaś w zapleczu narracji dydaktycznej funkcjonuje któreś $\mathrm{z}$ wcieleń postmodernistycznych rozumień istoty historiografii. Uciekając przed przemocą klasycznej, modernistycznej, naukowej historii, wpada się, jak widać, w pułapki nowych mód i nowych ideologii.

Drugi sposób ucieczki, polega na tym, że zamiast historii eksponuje się pamięć. Na całym świecie przeżywamy nadejście czasu pamięci - pisał wybitny historyk francuski Pierre Nora pod koniec XX wieku w eseju Czas pamięci, zwracając uwagę m.in. na materializację pamięci w kulturze współczesnej w postaci pomników, cmentarzy czy muzeów $^{46}$. Upamiętnienie ma wymiar etyczny, podczas gdy historiografia akademicka programowo odcinała się od wartościowania. Stąd miała wynikać właśnie moralna wyższość dyskursu pamięci. Badająca ten problem Ewa Domańska zauważa, że

pod koniec ubiegłego stulecia, w sposób niejako naturalny pamięć zaczęto stawiać w opozycji do historii, określając ją jako przeciw-historię, a dyskurs pamięci jako dyskurs anty-historyczny. (...) Podczas gdy historię określano jako instrument nacisku i identyfikowano z modernizmem, państwem, imperializmem, scjentyzmem i antropocentryzmem, pamięć traktowano jako uzdrawiające lekarstwo i narzędzie odkupienia, odnosząc ją do postmodernizmu i „wyzwolenia” grup, których historia pozbawiła głosu ${ }^{47}$.

W rezultacie tego praktykowania polityki pamięci stworzono/ pojawiły się dwa nowe zagrożenia.

45 N. Davies, Smok wawelski nad Tamiza. Eseje, polemiki, wykłady, Kraków 2001, s. 207.

46 Zob.: "Res Publica Nowa", nr 7, lipiec 2001, s. 37.

47 E. Domańska, Wprowadzenie [w: Pamięć, etyka i historia, Poznań 2002, s. 16 


\section{DWIE PUŁAPKI POLITYKI PAMIĘCI}

W literaturze przedmiotu zwraca się uwagę na fakt, iż postmodernistyczna poetyka pamięci operuje quasi-religijnym dyskursem, w oparciu o słownik wypełniony tak obcymi historii naukowej pojęciami, jak: wstyd, wina, odkupienie, zadośćuczynienie, wybaczenie, ukojenie, wypełnienie czy katharsis. Pamięć jest tu rodzajem „kulturowej religijności", obrzędowego obchodzenia/świętowania kolejnych rocznic, a nawet krótszych interwałów czasowych; sposobem na radzenie sobie z przeszłością, na zasadzie jej „zaczarowania”48. Ale wkrótce przyszło spostrzeżenie, iż

pamięć jest ściśle powiązana z pojęciem władzy. To, co ludzie pamiętają, i jakie emocje z tymi wspomnieniami wiąża, wplywa na ich decyzje, postawy i zachowania. (...) Polityka pamięci ucieka się nieraz do przemocy - zarówno bezpośredniej, polegającej np. na administracyjnej decyzji - wbrew opinii mieszkańców - o zmianie nazwy ulic lub usunięciu pomników i innych symboli nieakceptowanych przez elity władzy, reprezentujące dominującą wspólnotę pamięci, jak i przemocy symbolicznej ${ }^{49}$.

Z drugiej strony, polityka pamięci to także kwestia społecznej odpowiedzialności historyka wobec wyzwań współczesności. Nie może on nie zabierać głosu, milczeć, gdy dostrzega w dniu dzisiejszym niebezpieczne historyczne paralele.

Czy umarli mogą naprawdę należeć do kogokolwiek $?^{50}$, pyta Timothy Snyder w kontekście sporów o politykę pamięci. Reżimy nazistowski i sowiecki zamienily ludzi w liczby, spośród których część możemy tylko szacować, część umiemy zaś odtworzyć ze sporą precyzją, Jako naukowcy musimy określić te liczby i przedstawić je we właściwym kontekście. Jako humaniści musimy nadać im z powrotem ludzki wymiar. Jeżeli zadanie to się nie powiedzie, oznaczać to będzie, że Hitler i Stalin uksztaltowali nie tylko nasz świat, ale i nasze czlowieczeństwo ${ }^{51}$.

Odpowiedzią samego Snydera na to niebezpieczeństwo narodowej polityki pamięci stała się rozwijana przez niego tzw. historia transnarodowa ${ }^{52}$, pozwalająca nie

48 K. L. Klein w artykule On the Emergence of Memory in Historical Discourse, "Representations" no. 69, Special Issue: Grounds for Remembering, Winter 2000, pp. 127-150. Znakomicie dekonstrukcję tego "zaczarowania” przeprowadził ponad 40 lat temu Jerzy Kmita, zob.: Czarnoksięstwa humanistów. Fundacja Instytutu im. Jerzego Kmity. Dzieła wybrane, T. XVI, Poznań 2015.

49 L. M. Nijakowski, Baron Münchhausen czyli o polskiej polityce pamięci, „Przegląd polityczny” 2006, nr 75, s. 54-56.

50 T. Snyder, Skrwawione ziemie. Europa między Hitlerem a Stalinem, Warszawa 2011, s. 438.

51 Tamże, s. 440.

52 Piszę o tym obszerniej w studium Historia transnarodowa Timothy Snydera [w: ] J. Pomorski, Spoglądając w przeszłość. Studia i szkice metahistoryczne, Lublin 2017. 
tylko zrozumieć genezę zbrodni ludobójstwa na skrwawionych ziemiach ${ }^{53}$, ale także stawiać fundamentalne pytania, o pożądany kierunek (czytaj: o moralną wartość) zmiany i obowiązek historyka stałego reflektowania nad nim:

masowy mord rzeczywiście wiąże sprawców z tymi, którzy wydają im rozkazy. Czy to właściwy rodzaj lojalności politycznej? Terror w istocie konsoliduje pewne rodzaje reżimów. Czy są to reżimy godne uznania? Zabijanie cywilów leży w interesie pewnych rodzajów przywódców. Nie powinniśmy dowiadywać się, czy wszystko to jest prawdą z historycznego punktu widzenia, ale pytać: co jest pożądane? Czy ci przywódcy są dobrymi przywódcami, a te reżimy dobrymi reżimami? Jeżeli nie, należy zapytać: w jaki sposób można zapobiec takiej polityce ${ }^{54}$.

\section{METAFORY FUNDAMENTALNE 111 RP JAKO PUŁAPKI INTERPRETACY]NE}

Po tych uwagach, chciałbym przejść do sposobów manifestowania (się) odwracania się od historii jako wyrazu politycznej poprawności w warunkach polskich. Jest to pośrednio pytanie o metafory fundamentalne III RP. Pierwszą i podstawową z naszego punktu widzenia (czytaj: stosunku do przeszłości) jest metafora „grubej kreski”. Odgradzanie się od przeszłości, polityka zapomnienia, a nie pamięci o tym, co było przed 1989 rokiem stała się w nowej rzeczywistości elementem poprawności politycznej. Należało wypić „bruderszaft z Kainem” (kolejna metafora) i nie zaglądać mu już do życiorysu, koncentrując się na bieżących zadaniach i wyzwaniach, jakie niesie przyszłość. Ucieczka od historii była ucieczką od własnej trudnej przeszłości, od podziałów na „my” i „oni”. Z drugiej jednak strony w ówczesnym dyskursie publicznym, zwłaszcza na początku lat dziewięćdziesiątych, mowa jest o „odkłamywaniu historii”, o rugowaniu „białych plam”, o „przywracaniu pamięci”, a więc o zjawiskach charakterystycznych dla zwrotu ku historii. W moim przekonaniu jest to pozorne pęknięcie świadomości historycznej ${ }^{55}$. Ówczesna polityka historyczna polegała bowiem z jednej strony na kontynuacji tego, co można by nazwać „upolitycznianiem historii”, czyli walki o „historyczny rząd dusz” nad Polakami kosztem prawdy historycznej,

53 Snyder idzie tu tropem F. Fureta: By zrozumieć magię tych dwóch wielkich ideologii, komunizmu ifaszyzmu, trzeba cofnać się do okresu sprzed katastrof, których byty źródtem: do momentu, gdy symbolizowaly jedynie nadzieje. Trudność tej retrospekcji polega jednak na tym, że musi ona objąć stosunkowo krótki okres między ideą nadziei a ideą katastrofy; wydaje się prawie niemożliwe, by po roku 1945 pamiętać jeszcze narodowy socjalizm z roku 1920 czy 1930 jedynie jako pomyślną obietnicę. François Furet, Przeszłość pewnego złudzenia. Esej o idei komunistycznej w XX w., Warszawa 1996, s. 17.

54 T. Snyder, dz. cyt., s. 433. Zob. także tegoż Dwadzieścia przykazań wolnych ludzi w „Gazecie Wyborczej” z 19/ 20-11-2016.

55 Pisałem o tym szerzej w: Ucieczka od historii jako element poprawności politycznej - tezy, [w:] Pamięć i polityka historyczna. Doświadczenia Polski i jej sąsiadów, Łódź 2008, s. 107-116. 
z drugiej zaś strony na stopniowym „uhistorycznianiu polityki”, czyli nadawania jej legitymizacji poprzez zakorzenienie w tradycji narodowej.

Jeśli za L. Nijakowskim zdefiniujemy politykę pamięci jako

wszelkie intencjonalne działania polityków i urzędników, które mają na celu utrwalenie, usunięcie lub redefinicję określonych treści pamięci społecznej. Działanie to może mieć charakter zarówno innowacji, jak i zrutynizowanych praktyk ${ }^{56}$,

to można powiedzieć, iż polityka pamięci stała się w III RP składową politycznej poprawności. Protesty przeciwko tej poprawności były do roku 2005 nieliczne i pochodziły nie z głównego nurtu ówczesnej debaty publicznej, ale z jej marginesu.

\section{KOLEJNE DWIE PU ŁAPKI: HISTORIA W SŁUŻBIE PROPAGANDY I HISTORIA W SŁUŻBIE DUSFUNKCY]NEGO KAPITA ŁU SPO ŁECZNEGO}

Jakie formy przybiera „ucieczka od historii” $\mathrm{w}$ „świat bez historii” w III RP? Po pierwsze, jest to mitologizowanie własnej przeszłości. Historia niosła bowiem w XIX wieku zmitologizowane treści, tworzone na użytek powstającego nacjonalizmu. Aby budować narody, odwoływano się do zmyślonych opowieści. (...) Jednak krzewienie tych mitów i legend $w$ czasach pozbawionych realnego zagrożenia grozi uprawianiem propagandy - słusznie zauważa Andrzej Chwalba ${ }^{57}$. Historia w służbie kapitału społecznego i historia w służbie propagandy to jednak dwie całkowicie różne praktyki społeczne. Autor wydanej ostatnio książki na temat kapitału społecznego, prof. Piotr Sztompka mocno to akcentuje:

nie wszystkie relacje stanowią kapitał, Taką wartość mają tylko relacje pozytywne, a wśród nich w szczególności relacje moralne: zaufanie, lojalność, wzajemność, solidarność, szacunek i sprawiedliwość. Relacje przeciwne, negatywne (wrogie, konfliktowe), a zwłaszcza relacje amoralne, cyniczne i egoistyczne, pozbawione zaufania, lojalności, wzajemności, solidarności, szacunku i sprawiedliwości, stanowią obciążenie jednostek lub zbiorowości, utrudniając, a nawet uniemożliwiając im osiągnięcie zarówno ich celów, jak i satysfakcji z samej relacji czy uczestnictwa w grupie. To swoiste bankructwo kapitału społecznego ${ }^{58}$.

Zapewne ma rację w związku z tym Tomasz Kizwalter, gdy pisze, że jeśli założymy, że dzisiejsza Polska stanowi rzeczywistą część późnonowoczesnej Europy, to wrażenie anachroniczności działań polityczno-historycznych

\footnotetext{
56 Tamże, s. 54.

57 A. Chwalba, dz. cyt., s. 172.

58 P. Sztompka, Kapitat spoteczny, s. 335.
} 
musi być uderzające. (...) skoro zaleca się strategie, które królowały w Europie przed stu laty, to jakże tu mówić o modernizacyjnym optymizmie ${ }^{59}$.

A przecież podstawowym jest pytanie, jaki stosunek do historii sprzyja zmianom modernizacyjnym, a jaki utrwala postawy pasywne?

Komentując potrzebę stabilizacyjnego oddziaływania przeszłości, antropolog Loren Eiseley twierdził, iż

ogólnie rzecz ujmując, historia ludzkości jest zasadniczo historią istoty, która zrezygnowała $\mathrm{z}$ instynktu i zastąpiła go tradycją kulturową oraz z trudem dokonanym rozwojem umiejętności myślenia dyskursywnego. Lekcje przeszłości słusznie uznane zostały za konstrukcję dającą poczucie bezpieczeństwa w podejmowaniu kroków ku nieznanej przyszłości ${ }^{60}$.

Historyczne bezpieczeństwo ontologiczne to, jak pamiętamy z pierwszej części tego tekstu, wspólnotowe poczucie trwania (ciągłości) i porządku historycznego wydarzeń, w tym rozumienia zdarzeń wykraczających poza horyzont bezpośredniego doświadczenia jednostki - tego, co przydarza się jej na co dzień. Zatem respektująca powyższe założenia szkolna (i uniwersytecka) praktyka edukacyjna w zakresie nauczania historii, programowo przekraczająca wąski krąg doświadczeń własnych, jest/ może być ważnym elementem budowy kapitału społecznego, tak ważnego dla zapewnienia Polsce i Polakom trwałych możliwości rozwojowych. Może pokazywać ona bowiem, że zmiana społeczna jest w ogóle możliwa i że myślenie w kategoriach zmiany jest fundamentem „świata z historią”, jak nauczał kiedyś Jerzy Topolski ${ }^{61}$. Zerwanie z polityczną/historyczną poprawnością III RP oznacza zatem szansę na powrót „świata z historią” i wykorzystywania historii do świadomego/podmiotowego tworzenia dziejów (co dobrze oddaje np. termin historicity - w tradycji anglosaskiej). Z drugiej zaś strony, jeśli za każdą zmianą władzy będziemy „majstrować” przy nauczaniu historii, utracimy to nasze polskie historyczne bezpieczeństwo ontologiczne. Sztompka pisze w zbliżonym kontekście o dysfunkcjach kapitału społecznego, możliwych jego negatywnych skutkach, np. wtedy, gdy otwarcie kapitału społecznego dla „swoich” może oznaczać dyskryminację (każdą, polityczną, ekonomiczną, religijną, edukacyjną, itp.) „obcych”62.

59 T. Kizwalter, Historia malowana, „Przegląd polityczny” 2006, nr 77, s. 91.

60 Cyt. za: E. T. Hall, Poza kultura, Warszawa 1984, s. 134-135.

61 J. Topolski, Świat bez historii, Warszawa 1976.

62 Oto wypowiedź Szczepana Twardocha w rozmowie z Emilią Padol [z wywiadu dla: „Magazyn O!Kultura” $\mathrm{nr} 7$, 12.10. 2016]: Mogę pani przede wszystkim powiedzieć, na jakim poziomie polityka mnie nie interesuje. Na poziomie emocji, bo wtedy mnie śmieszy albo brzydzi, częściej śmieszy. A 90 proc. polskiej polityczności to są emocje i dlatego odmawiam $u d z i a t u$ w polskiej debacie o polityce, ponieważ $w$ Polsce nie ma debaty o polityce, $w$ Polsce sa wytacznie dwie rozemocjonowane narracje, obie praktycznie ignorujące rzeczywistość, a żywiące się sobą nawzajem, żywiące się nawzajem strachem przed drugą. Branie w tym udziału jest płonne, z tego nic nie wynika - poza różnymi złymi rzeczami dla naszego państwa. http://ksiazki. onet.pl/szczepan-twardoch-nie-mamy-pojecia-czym-jestesmy-wywiad/v7v8lp [dostęp: 04-06-2017]. 
Edward Banfield już przed wielu laty w The Moral Basis of a Backward Society (1958) pisał o stosowaniu reguł moralnych tylko wobec swoich, podczas gdy zasady te nie obowiązują wobec obcych, których bez skrupułów wykorzystujemy i manipulujemy nimi dla całkowicie egoistycznych korzyści, co nazwał amoralnym familizmem. Sytuując to zjawisko w warunkach polskich, P. Sztompka zauważa:

taka solidarność jest silna ślepą lojalnością wewnętrzną wobec przywódcy, a odgradza się szczelnym murem niechęci i agresji od szerszego społeczeństwa. Taka solidarność nie lączy, lecz dzieli, nie integruje, lecz wyklucza: tworzy nieprzezwyciężoną dychotomię „my - oni”, rezerwując wszelkie cnoty tylko dla swoich, a wszelkie grzechy przypisując obcym, ba, odmawiając im nawet ludzkiej godności. To nie jest solidarność współpracy, lecz solidarność oblężonej twierdzy. Wspólna przestrzeń etyczna występuje tylko wewnątrz zamkniętej grupy, na zewnątrz natomiast, wobec innych grup, tolerancję zastępuje ksenofobia, zaufanie - paranoiczna podejrzliwość, życzliwość - brutalna wrogość, debatę zastępują inwektywy, a dobro wspólne - wąski interes grupowy ${ }^{63}$.

\section{PUŁAPKA NACJONALIZMU}

Amoralny familizm może mieć także swoją emanację narodową w postaci nacjonalizmu. Jak zatem nie wpaść w pułapkę nacjonalizmu, gdy chce się pisać historię XX stulecia w paradygmacie historii afirmatywnej? Może wystarczy przypomnieć sobie o fundamentalnym rozróżnieniu między patriotyzmem a nacjonalizmem, jakiego dokonał Jan Paweł II w Pamięci i tożsamości:

Tożsamość kulturalna i historyczna społeczeństw jest zabezpieczona i ożywiana przez to, co mieści się w pojęciu narodu. Oczywiście, trzeba bezwzględnie unikać pewnego ryzyka: tego, ażeby ta niezbywalna funkcja narodu nie wyrodziła się w nacjonalizm. XX stulecie dostarczyło nam pod tym względem doświadczeń skrajnie wymownych, również w świetle ich dramatycznych konsekwencji. W jaki sposób można wyzwolić się od tego zagrożenia? Myślę, że sposobem właściwym jest patriotyzm. Charakterystyczne dla nacjonalizmu jest bowiem to, że uznaje tylko dobro własnego narodu i tylko do niego dąży, nie licząc się z prawami innych. Patriotyzm natomiast, jako miłość ojczyzny, przyznaje wszystkim innym narodom takie samo prawo jak własnemu, a zatem jest drogą do uporządkowanej miłości społecznej ${ }^{64}$.

63 P. Sztompka, Kapitat społeczny, s. 15. Zob. też badania socjologiczne prof. Krystyny Daszkiewicz nad Klimatami bezprawia w PRL.

64 Jan Paweł II, dz. cyt., s. 73. 


\section{PUŁAPKI (I SZANSE) „NARRACYJNEGO KREOWANIA" RZECZYWISTOŚCI HISTORYCZNE]}

Praktycznie każde znaczące wydarzenie historyczne już zaistniałe, ma swoje drugie „życie po życiu”, historię swojej narratyzacji, wpisaną w przestrzeń międzyludzkiej komunikacji, gdzie - powtórzę za Umberto Eco - mamy do czynienia z kreowaniem rzeczywistości prawdziwszej niż sama rzeczywistość. Smoleńsk 10 kwietnia 2010 roku, powiedzmy, żeby nie unikać tematów najtrudniejszych w debacie publicznej-jak prawie każde z ważnych dla wspólnoty wydarzeń historycznych - ma swoje „życie po życiu”. Traumatyczne doświadczenie wspólnoty już w kilka godzin po Wydarzeniu staje się przedmiotem narratyzacji, nazwania tego, co się wydarzyło (językowego kreowania rzeczywistości, jak powiedziałby metodolog za kognitywistami Peterem Bergerem i Thomasem Luckmannem ${ }^{65}$ ). To jak najbardziej normalna praktyka. Próbujemy jakoś oswoić to przejmujące doświadczenie przez poręczne odwołanie do nieodległej a symbolicznej przeszłości (metafora „drugiego Katynia”), zrozumieć, co się stało i jak do takiej tragedii dojść mogło. Emocje - jak już wiemy dzięki neuronauce - są nie mniej istotne niż suche fakty, a dla homo historicus nawet bardziej. Zwłaszcza te zbiorowe.

Praktyka społeczna rozgrywa się w określonej przestrzeni międzyludzkiej, wyznacza kontekst historyczny dla działań jednostek i grup społecznych. A w działaniach tych kierujemy się - jak poucza nas Randall Collins - przede wszystkimi emocjami. Jakie to ważne dla zrozumienia najnowszych dziejów Polski w latach 1944-1947 dostrzegł i znakomicie pokazał Marcin Zaremba w Wielkiej trwodze, opisując codzienność strachu. We Wstępie pisał:

Przestrzenią nieomal zupełnie nieprzedstawioną przez badaczy pozostaje świat zbiorowych wyobrażeń, opinii i emocji. Naszym, historyków, zadaniem jest opowiadanie historii ludzkiej, a zatem powinniśmy również zapytać o emocje, spróbować odtworzyć te najważniejsze, zastanowić się, z czym się wiązały i jaki miały wpływ na dalsze zachowania i postawy ludzi. Wydarzenia nabiorą pełni, staną się bardziej zrozumiałe, gdy osadzimy je w kontekście. Tego jestem pewien ${ }^{66}$.

Analogicznie nie da się zrozumieć historii Polski lat 2010-2016 bez badania emocji, które nam w tych latach towarzyszyły. Trzeba też wejść na poziom gramatyki sterującej wówczas zachowaniami społecznymi. To wyzwanie badawcze jest ciągle otwarte, jest wciąż przed nami.

65 T. Luckmann, P. L. Berger, Społeczne tworzenie rzeczywistości, Warszawa 2010.

66 M. Zaremba, Wielka trwoga. Polska 1944-1947, Kraków 2012, s. 18. 


\section{JAKIEJ HISTORIOGRAFII POLACY DZISIAJ POTRZEBUJĄ?}

Dotykamy w ten sposób ponownie najważniejszego dla środowiska historyków pytania. Poszukując na nie odpowiedzi, chciałbym podążyć tropem Dariusza Stoli, który przed kilkoma laty, tak widział ten problem:

Przeglądając publikacje poświęcone historii Polski pod rządami PPR/PZPR wydane w ostatnich latach, odczuwam rosnący niedosyt. (...) O PRL wiemy coraz więcej i wiedza ta ma coraz szerszą i solidniejszą podstawę źródłową. Miejsce dawnych spekulacji zastąpiły rzeczowe ustalenia, uzbrojone w szczegółowe przypisy archiwalne. Skąd zatem ów niedosyt? Otóż im większy jest stos „faktów”, pracowicie ustalanych przez historyków, tym silniejsze mam przekonanie, iż dzieje PRL nie byly tylko ich sumą, że prosta kumulacja wiedzy o faktach nie wystarcza. Rosnąca szczegółowość opisów nie prowadzi do lepszego, głębszego rozumienia przeszłości lub prowadzi doń coraz wolniej. Najwyraźniej ilość nie przechodzi w jakość sama z siebie. Tymczasem pragnienie takiego pogłębionego rozumienia rośnie. Umacnia się przekonanie (chyba nie tylko w piszącym te słowa), iż ponad, pod czy też pomiędzy tak pracowicie opisywanymi wydarzeniami musi być jakiś zespół prawidłowości, „wyższy porządek” czy „struktura” (jak powiedzieliby strukturaliści), które nadawały PRL (lub nadają opowieściom o PRL) konieczne minimum wewnętrznej spójności oraz pozwalają wyróżnić dekady rządów komunistycznych jako swoisty i odrębny okres naszych dziejów. Wspomniany niedosyt jest zatem niedosytem teorii - ogólnych koncepcji wyjaśniających, porządkujących i spajających dzieje PRL. Warto podkreślić, że trapi on historyka, nie mającego ani ambicji, ani przygotowania do tworzenia teorii społecznych czy politycznych, który potrzebuje jednak pewnych teoretycznych punktów oparcia i kluczy interpretacyjnych. Bez tego trudno jest dobrze wypełniać tę podstawową rolę historyka wobec (zainteresowanych przeszłością) nie-historyków, która polega na odnajdowaniu sensu przeszłych wydarzeń (lub nadawania im tego sensu) ${ }^{67}$ [podkreślenia moje - JP].

Jest to pytanie o gramatykę PRL-u, o intelektualne nawigowanie/poznanie na tym poziomie. Nie o proste rejestrowanie minionych zdarzeń przecież ma nam chodzić, ale o to, co nimi sterowało: o zespół reguł sterujących poszczególnymi praktykami społecznymi w tamtych czasach, do których historyk poznawczo chciałby dotrzeć ${ }^{68}$. Bowiem tylko w ich świetle wydarzenia historyczne tracą swój przygodny charakter,

67 D. Stola, O dalszy rozwój badań nad socjalistycznymi praktykami społecznymi. Uwagi o stanie i możliwościach refleksji nad charakterem PRL? [w:] Obrazy PRL. O konceptualizacji realnego socjalizmu w Polsce, red. K. Brzechczyna, Poznań 2008, s. 131.

68 Świetnym przykładem takiej rekonstrukcji reguł sterujących, w tym przypadku propagandą komunistyczną w latach 1944-1956, jest praca Mariusza Mazura O człowieku tendencyjnym ... : obraz nowego człowieka w propagandzie komunistycznej w okresie Polski Ludowej i PRL 1944 - 1956, Lublin 2009. 
odkrywając stojące za nimi „prawidłowości”, „wyższy porządek” czy „struktury”; odsłaniają gramatykę historii - właściwy przedmiot poznania w historiografii ${ }^{69}$. Ale jako metodolog i badacz historiografii dziejów najnowszych jestem przekonany do konieczności stosowania przez historyków jeszcze przynajmniej jednej perspektywy badawczej, na którą chciałbym w kontekście naszej debaty zwrócić uwagę. To praktykowanie historii alternatywnej. Alexander Demandt pisze w Historii niebyłej: Rozpatrywanie $z$ darzeń, do których $w$ historii nie doszło, jest, mimo zrozumiałych watpliwości, konieczne, możliwe, mimo znacznych trudności, i pouczające ze względu na poznanie historii $\boldsymbol{r} \boldsymbol{e} \boldsymbol{a} \boldsymbol{l} \boldsymbol{n} \boldsymbol{e} \mathbf{j}^{70}$. Pójdźmy jego tropem.

Co by było, gdyby - pomijając wersję zamachu - mgła nad Smoleńskiem zawisła nie 10, ale 7 kwietnia i lot Tu-154M Lux nr 101 skończył się tak samo tragicznie, jak ten trzy dni później? Giną: Donald Tusk, Bogdan Zdrojewski, Krzysztof Kwiatkowski, Cezary Grabarczyk, Bogdan Klich, Tomasz Arabski, Paweł Graś, Jacek Cichocki, Grzegorz Schetyna, Rafał Grupiński, Andrzej Halicki¹ ${ }^{71}$ a także Andrzej Kremer i Andrzej Przewoźnik (obydwaj zginęli faktycznie 10 kwietnia) i wielu innych, m.in. Lech Wałęsa, Tadeusz Mazowiecki, Andrzej Wajda, Norman Davies, Paweł Machcewicz. Historycznie rzecz biorąc, było to możliwe, jeżeli państwo polskie nie potrafiło zabezpieczyć warunków bezpieczeństwa najważniejszych osób (warunek wystarczający dla zajścia wydarzenia) i w sprzyjających okolicznościach (w sensie warunku sprzyjającego) do analogicznej katastrofy mogło dojść w każdej chwili. W tym zakresie państwo polskie faktycznie istniało „tylko teoretycznie”, by posłużyć się skrótem myślowym jednego z nagranych jego urzędników.

Jak wyglądałaby Polska po traumie 7 kwietnia? Jak wyglądałaby codzienność tych sześciu ostatnich lat? Czy odmiennie od tej, jaką znamy? Gdzie bylibyśmy dzisiaj? By zrozumieć to, co się stało i gdzie jesteśmy obecnie, historyk najnowszy nie może nie brać pod uwagę historycznych scenariuszy alternatywnych. Musi takie kontrfaktyczne pytania stawiać. Próbowałem to zrobić na swoim seminarium doktoranckim i było to inspirujące ćwiczenie, także w wymiarze etycznym, w wymiarze zmagania sumień. W warstwie tej drgają zwycięstwa i upadki. Historia ich nie pokrywa, lecz uwydatnia. Uczy pokory wobec dramatu ludzkich losów i uczy szacunku dla innego spojrzenia. A pokora i wzajemny szacunek to wartości, które trzeba pielęgnować nie tylko w naszym środowisku i nie tylko na użytek debat.

69 Przedmiot poznania historycznego odróżniam od przedmiotu badania historycznego, ten ostatni sprowadza się do tematów, jakie w pracach historyków są podejmowane.

70 A. Demandt, Historia niebyta. Co by byto, gdyby...?, Warszawa 1999, s.10.

71 Zatem wszyscy z „Platformy Obywatelskiej”; o ile dobrze pamiętam z „Prawa i Sprawiedliwości” na pokładzie byli wtedy jedynie senator Grzegorz Banaś i posłanka Maria Zuba. 